\title{
Goal-Oriented Management
}

\section{in Innovations' Promotion with a Website*}

\author{
Galina Kurcheeva, Maxim Bakaev \\ Automated Control Systems department \\ Novosibirsk State Technical University \\ Novosibirsk, Russia \\ kurcheeva@yandex.ru; maxis81@gmail.com
}

\begin{abstract}
The present day's efficient management in innovations' promotion is based on development and implementation of information and communication technologies and systems that include a website. Strengthening the role of marketing in driving innovation contribute to the processes occurring in the world economy, which determine the development of innovative economy, among which are increasing the speed of propagation of innovation and development capabilities of innovative imitation by the development of information technology, network economy and the emergence of additional technical capabilities allowing to include all participants into the innovation process. The article summarizes the steps for assessing effectiveness and efficiency in fulfilling the goals of innovations' marketing, and also includes a developed approach for evaluating the potential of marketing components. This approach allows assessing chances of achieving the goals of innovations' promotion and promotion risks as the difference between the goal's reference value and the value of the innovations' marketing potential. Organization's ability to innovate depends on the availability of all the necessary resources, but in network economy information and communication get prime importance. So, in the article we also assess potential of a website as a tool for promotion of innovations, giving example for a particular IT company.
\end{abstract}

Keywords-IT management, web promotion, potential and risks management, innovative technologies, goals

\section{INTRODUCTION}

Promotion of innovations is gaining in importance as development of innovative economy in the world is shaped by the ongoing processes:

1. The pace of the innovations distribution is increasing, together with opportunities for development of innovative imitations. This is due to advancements in information and communication technologies (ICT), network economy and enhancements in technological capabilities that allow bringing all the stakeholders into the innovative process.

2. The necessity for developing tools for involving a significant number of participants from various industries and fields into innovative process, e.g. via benchmarking. This ascertains the importance of actions' coordination and balancing interests of both consumers and competitors.
3. Declining market demand on the whole and decrease in value for foodstuff and mass-market innovations, due to "loss" of the goods' uniqueness in the eyes of customers, as new products are released too often.

4. The process of innovations creation and acceptance is influenced by government structures and social organizations, which are able to significantly help or block a release success.

5. Active emergence and development of non-material goods markets (services, information, knowledge) that calls for novel methods of promotion and sales.

The nature of interaction between agents in innovative economy and the particular influencing factors shape the success or failure of ideas, technologies, and innovations. Research in this field is not actively performed lately, though it should allow identifying resource and emotional dimensions in the interaction and the participants' willingness to promote and apprehend innovations. Currently, researchers note the lack of the interaction and coordinated decisions on all levels of innovative activities $[1,2,3]$. At the same time with the development of the Internet it became obvious that e-presence is now not just a critical success factor, but a necessity for any company's normal operations. Effective management of innovations' promotion today is based on ICT and a website has become an integral part of the arrangement [4, 5].

V.M. Glushkov, an influential Russian academician, among laws and principles of computerization identified the customer's effect on sales [6]. The increase in the number of relations between producers, consumers, competitors, employees and etc. leads to the growth in management complexity. Failure to harness the whole multi-plex of the relations between the managed objects causes decrease of the management precision and, further, losses on various stages of innovations promotion. In this, the promotions management gains particular importance, since marketing is philosophy and technology of the modern business management, while innovations' marketing is promotion of innovations that is based on modern ICT [7]. The innovations' marketing is the set of processes, methods, software and internet technologies required to assess the promotion prospects, reduce the necessary duration of innovations acceptance $[8,9]$.

\footnotetext{
*The reported study was funded by RHSF/RFBR according to the research project No. 17-32-01087 a2.
} 
Website, as an innovations' marketing tool, is an integral part of IT. It is aimed on implementation of the organization's goals on the operational management level, making tactical decisions; allows implementation of monitoring, control and feed-back; ensures systematic approach towards innovations' promotion processes. In this, management must be founded on a popular principle in marking - regulations based on feedback $[10,11]$. Goal-oriented management contributes to the increase of innovations' distribution and opportunities for development of innovative imitations, and is considered a solid systematic approach as well, since it allows estimating both the progress towards a goal for every component of the innovation cycle and the website capabilities on the whole. Thus, in the paper we propose the method for assessing promotion risks as the difference between the referential goal and the innovations' promotions potential. Section 2 is dedicated to the overview of goal-oriented management in promotion of innovations, while in Section 3 we further refine the proposed approach and provide an evaluation example.

\section{MANAgEMENT GoALS In InNOvations' Promotion}

\section{A. Management Goals in Innovative Marketing}

The goals of marketing activities correspond to the overall goals of the company development. The principal marketing goal is known to be satisfaction of the customers' needs, while major goals for a company are increase of capital stock, turnover, market share, etc. - and their accomplishment is possible of the marketing goal is fulfilled [12]. The systematic approach towards innovations' marketing effectiveness allows us to operationalize the principal innovations' marketing goal into concrete measurable goals (Table I).

So, the principal goal of the innovations' marketing, i.e. satisfying customers' needs for new products, includes shortterm and operating forecast regarding of the future needs. In this, providing for the current needs for new products splits into sev-eral sub-goals or second-level goals, which include increasing brand and ads aware-ness, better sales, greater market share and gross margin, better satisfaction of customers, increase in the overall number of customers, etc.

The goals for forecasting and new needs creation are selected according to experts' opinions that were obtained in the survey with professionals, managers and customers participating into innovations in milk processing industry, finance technologies and service industry. The total sample was 120 people ( $48 \%$ male, $52 \%$ female), of whom $54 \%$ were older than 25 and had more than 5 years of work experience. There were 76 professionals, 23 managers and 21 customers ( $10 \%$ being businesses and $90 \%$ individuals) who actively participated in the innovative process. For instance, websites of companies in milk processing industry, commercial banks and etc. do undertake campaigns to get customers to participate in new product's advancement to the innovation stage. The customer companies were Center for Finance Technologies Ltd. and Sberbank of Russia JSC, who develop new banking products together.

As the result of our selection of goals, their major part $(20 \%$ to $45 \%)$ the ones as-sociated with customer relations management (CRM), customer profile creation and needs monitoring, deployment of corporate information systems capable of maintaining databases of not merely customers, but of employees, partners, competitors, social organizations and so on. The set also included such modern tools and TRIZ (theory of the resolution of invention-related tasks) technologies, scoring models, imitation models that can make up virtual reality for creating new consumer needs [13].

TABLE I. IDENTIFICATION OF GOALS IN INNOVATIONS' MARKETING MANAGEMENT

\begin{tabular}{|c|c|c|}
\hline $\begin{array}{l}\text { Principal } \\
\text { goal }\end{array}$ & First level goals & Second level goals \\
\hline \multirow{13}{*}{$\begin{array}{l}\text { Satisfying } \\
\text { customers' } \\
\text { needs in } \\
\text { new } \\
\text { products, } \\
\text { based on } \\
\text { increasing } \\
\text { the } \\
\text { effective- } \\
\text { ness of } \\
\text { marketing } \\
\text { tools in the } \\
\text { company } \\
\text { innovative } \\
\text { activities. }\end{array}$} & \multirow{5}{*}{$\begin{array}{l}\text { 1. Ascertaining } \\
\text { forecast and } \\
\text { creation of future } \\
\text { needs based on } \\
\text { marketing } \\
\text { innovations. }\end{array}$} & $\begin{array}{l}\text { 1.1. Developing CRM systems to } \\
\text { create profile of the customer. }\end{array}$ \\
\hline & & $\begin{array}{l}\text { 1.2. Developing ERP systems to } \\
\text { create databases of customers, } \\
\text { employees, partners, competitors, } \\
\text { social organizations, etc. } \\
\text { (annually). }\end{array}$ \\
\hline & & $\begin{array}{l}\text { 1.3. Application of scoring } \\
\text { models to assess and model } \\
\text { heuristic thinking of individuals. }\end{array}$ \\
\hline & & $\begin{array}{l}\text { 1.4. Application of TRIZ } \\
\text { technologies to form a model of } \\
\text { future needs. }\end{array}$ \\
\hline & & $\begin{array}{l}\text { 1.5. Modeling virtual reality for } \\
\text { creating new needs. }\end{array}$ \\
\hline & \multirow{8}{*}{$\begin{array}{l}\text { 2. Providing for } \\
\text { and monitoring } \\
\text { current customers' } \\
\text { needs for new } \\
\text { products, based } \\
\text { creasing } \\
\text { effectiveness } \\
\text { innovations' } \\
\text { marketing. }\end{array}$} & $\begin{array}{l}\text { 2.1. Increasing monthly sales by } \\
10 \% \text { (to } 280 \text { items). }\end{array}$ \\
\hline & & $\begin{array}{l}\text { 2.2. Increasing brand awareness } \\
\text { (by } 3 \% \text { per month). }\end{array}$ \\
\hline & & $\begin{array}{l}\text { 2.3. Increasing ads awareness } \\
\text { (by } 5 \% \text { per month). }\end{array}$ \\
\hline & & $\begin{array}{l}\text { 2.4. Increasing market share } \\
\text { by } 1.5 \% \text { per month (up to } 15 \% \\
\text { total market share). }\end{array}$ \\
\hline & & $\begin{array}{l}2.5 \text {. Increasing gross margin } \\
\text { by } 3 \% \text { per month (up to USD } 2000 \text { ) }\end{array}$ \\
\hline & & $\begin{array}{l}\text { 2.6. Increasing customer base } \\
\text { by } 5 \% \text { per month (up to } 16 \\
\text { thousand customers). }\end{array}$ \\
\hline & & $\begin{array}{l}\text { 2.7. Increasing the share of } \\
\text { satisfied customers (up to } 100 \% \text { ). }\end{array}$ \\
\hline & & $\begin{array}{l}\text { 2.8. Decreasing the share of } \\
\text { complaints (down to } 0 \% \text { ). }\end{array}$ \\
\hline
\end{tabular}

\section{B. Management Goals in Innovations' Promotion with a Website}

Feedback-based management is a popular basis for managing objects in economy and is a principle of major importance in cybernetics. Up until recently, positive assessment of a business could be achieved just by fulfilling financial indexes reflecting the results of organization's activities [14]. But in the modern economy, market and business processes' changes are accelerating, so operational accounting of CRM and market environment indexes are becoming crucial. So, the goals of innovations' marketing management with a website should be creating in accordance with the requirements, as shown in Table II.

It goes without saying that a website unleashes new opportunities and directions of innovative development for business. Websites become tools for innovations promotion, 
accumulating all the marketing components, such as pricing, assortment, promotion, and locations. On the other hand, there emerges the problem of website's rational organization for greater innovations' promotion effectiveness - and it relates, first of all, to the identification of goals. The higher level goals remain the same, but sub-goals on the second level become different, according to the same survey that we mentioned above. Top positions among the sub-goals were taken by benchmarking aimed on creation innovative customer, which is a new direction in Russian economy, associated with development of open innovations and innovative imitations, where consumer actively participates in discussing and finalizing innovations, performing the role of co-innovator. The fulfillment of the identified goals depends of the capabilities or potential of organization's innovations' marketing and the associated potential of the organization's website innovations' marketing.

TABLE II. IDENTIFICATION OF GOALS IN INNOVATIONS' MARKETING MANAGEMENT WITH A CORPORATE WEBSITE

\begin{tabular}{|c|c|c|}
\hline $\begin{array}{l}\text { Principal } \\
\text { goal }\end{array}$ & $\begin{array}{c}\text { First level } \\
\text { goals }\end{array}$ & Second level goals \\
\hline \multirow{9}{*}{$\begin{array}{l}\text { Satisfying } \\
\text { customer } \\
\text { needs } \\
\text { based on } \\
\text { increasing } \\
\text { effectivene } \\
\text { ss of the } \\
\text { organizatio } \\
\text { ns } \\
\text { innovative } \\
\text { activities. }\end{array}$} & \multirow{3}{*}{$\begin{array}{l}\text { 1. Ascertaining } \\
\text { forecast and } \\
\text { creation of } \\
\text { future needs } \\
\text { based on } \\
\text { marketing } \\
\text { innovations. }\end{array}$} & $\begin{array}{l}\text { 1.1. Employing benchmarking } \\
\text { for creating innovative customer } \\
\text { profile (in the course of } 3 \text { years). }\end{array}$ \\
\hline & & $\begin{array}{l}\text { 1.2. Using technologies for } \\
\text { collecting the customers' } \\
\text { demographic data. }\end{array}$ \\
\hline & & $\begin{array}{l}\text { 1.3. Using technologies for } \\
\text { bringing the customer into the } \\
\text { innovative process (up to } 100 \% \text { ). }\end{array}$ \\
\hline & \multirow{6}{*}{$\begin{array}{l}\text { 2. Monitoring } \\
\text { of the current } \\
\text { customers' } \\
\text { needs for new } \\
\text { products. }\end{array}$} & $\begin{array}{l}\text { 2.1. Decreasing "bounce rate" } \\
\text { (the number of visitors who } \\
\text { "reject" the website must go } \\
\text { down) }\end{array}$ \\
\hline & & $\begin{array}{l}\text { 2.2. Increasing the number of } \\
\text { website visitors (by } 2 \% \text { per } \\
\text { month, up to } 20 \text { thousand). }\end{array}$ \\
\hline & & $\begin{array}{l}\text { 2.3. Increasing the number of } \\
\text { registered visitors (up to } 20 \\
\text { thousand) }\end{array}$ \\
\hline & & $\begin{array}{l}\text { 2.4. Increase the number of } \\
\text { completed and submitted web } \\
\text { forms (by } 1 \text { per month). }\end{array}$ \\
\hline & & $\begin{array}{l}2.5 \text {. Increase the number of page } \\
\text { views (by } 1.5 \% \text { per month). }\end{array}$ \\
\hline & & $\begin{array}{l}\text { 2.6. Increase the number of } \\
\text { unique visitors by } 3 \% \text { per month } \\
\text { (up to } 12 \text { thousand). }\end{array}$ \\
\hline
\end{tabular}

\section{AsSESSING FULFILlMENT OF THE INNOVATIONS' PROMOTION GOALS}

The assessment of the innovations' marketing goals fulfillment in accordance to the proposed management framework should include the following stages:

1. Identifying the goals of the innovations' promotion based on desired goal values and the planned fulfillment results, both specified by experts.

2. Assessing the potential for the innovations' marketing, as the opportunity to reach the desired goal value. This allows identifying whether all the organization's capabilities are engaged, and how efficiently the marketing components take part in the innovations' promotion.

3. As the result, the promotion risks can be assessed, as the difference between the desired goal value and the innovations' marketing potential value. The risk assessment, in turn, allows planning measures for decreasing the risks, including insurance, redistribution, and diversification.

4. In accordance with the identified values for the innovations' marketing components' potential, the key factors for success and resistance can be specified, which further allows distributing investments or reallocating the limited marketing budget.

The method for innovations' marketing potential management proposed by the authors allows assessing the potential level depending of the selected business model, so that effectiveness of the future innovations is increased. Since ICT become the key tool in promotion, the velocity in business environment makes organizations employ new network forms of business. Indeed, the global international network compresses the business planning cycles, as well as decisionmaking, and both new opportunities and new threats emerge for realizing models of business and promotion. Accordingly, ICT, including corporate website, are prime necessity for any company, and the factors that affect the business effectiveness can be grouped per the well-known 4P components in marketing (product, place, price, promotion) [15], as shown in Table III:

- the ones aimed on promoting the actual innovations and fulfilling the business goals;

- the ones aimed on developing marketing innovations for promotion of the website itself.

So, let us describe the adapted algorithm for assessing the promotion potential $[16,17]$. There are $\mathrm{i}$ participants in the survey - in total, there were 102 people, aged 18 to $63.43 \%$ being male and $58 \%$ being female, - and $\mathrm{j}$ indexes (the 5 major ones are assessed).

1. Every index is the share of positive answers, i.e. $x j$ is the actual value for the $\mathrm{j}$-th index, which is evaluated as: $x_{j}^{0}=\mathrm{A} / \mathrm{D}$, where $\mathrm{A}$ is the number of participants who gave a positive answer, $\mathrm{D}$ is the overall number of participants. Knowing the actual values for the indexes, we create information array.

2. Define the relative measure of the $\mathrm{j}$-th index fulfillment of the target value $\tilde{x}_{j}$ that is set specially as 1 :

$$
\beta_{j}=\frac{x_{j}^{0}}{\tilde{x}_{i}}
$$

3. The weight (importance) of the $\mathrm{j}$-th index is evaluated:

$$
\alpha_{j}=\frac{\beta_{j}}{\sum_{j=1}^{n} \beta_{j}}
$$

where $\mathrm{n}$ is the number of components constituting the promotion potential. 
4. The complex assessment value is specified:

$$
C=\frac{1}{n} \sum_{j=1}^{n} \beta_{j}
$$

From the analysis, values for promotion potential assessment for each of the components can be obtained. Then they are to be sorted per their significance, so that most effective components for the website success can be selected.

TABLE III. THE ASSESSMENT OF THE INNOVATIONS' MARKETING POTENTIAL WITH A WEBSITE

\begin{tabular}{|c|c|c|c|c|c|c|}
\hline \multirow{2}{*}{$\begin{array}{c}\text { Marketing } \\
\text { potential } \\
\text { components }\end{array}$} & \multirow[t]{2}{*}{ Group of factors } & \multicolumn{2}{|c|}{ Values $(\max =15)$} & \multirow{2}{*}{$\begin{array}{l}\text { Relative fulfillment } \\
\text { measure, } \%\end{array}$} & \multirow{2}{*}{$\begin{array}{c}\text { Index weight, } \\
\%\end{array}$} & \multirow{2}{*}{$\begin{array}{c}\text { Component } \\
\text { assessment value, \% }\end{array}$} \\
\hline & & Actual & Ref. & & & \\
\hline \multirow[t]{3}{*}{ Promotion } & $\begin{array}{l}\text { 1. Brand } \\
\text { 1.1.Brand awareness }\end{array}$ & 38 & & 37.5 & 100 & 37.5 \\
\hline & $\begin{array}{l}\text { 2.Advertisement } \\
\text { 2.1. Context ads } \\
\text { 2.2. SEO } \\
\text { 2.3. SMM } \\
\text { 2.4. Banner ads } \\
\text { 2.5. Teaser ads }\end{array}$ & $\begin{array}{l}9 \\
3 \\
10 \\
4 \\
11\end{array}$ & $\begin{array}{l}15 \\
7 \\
10 \\
5 \\
15\end{array}$ & $\begin{array}{l}60 \\
43 \\
100 \\
80 \\
73.3\end{array}$ & $\begin{array}{l}16.8 \\
12.1 \\
28.1 \\
22.5 \\
20.6\end{array}$ & 72.1 \\
\hline & $\begin{array}{l}\text { 3. Website } \\
\text { 3.1. Sale actions } \\
\text { 3.2. Typography } \\
\text { 3.3. Copywriting } \\
\text { 3.4. Visitors traffic } \\
\text { 3.5. Conversion }\end{array}$ & $\begin{array}{l}14 \\
10 \\
14 \\
13 \\
13\end{array}$ & $\begin{array}{l}15 \\
10 \\
15 \\
15 \\
15\end{array}$ & $\begin{array}{l}93.3 \\
100 \\
93.3 \\
86.7 \\
86.7\end{array}$ & $\begin{array}{l}20.3 \\
21.7 \\
20.3 \\
18.8 \\
18.8\end{array}$ & 92.0 \\
\hline \multirow[t]{3}{*}{ Product } & 4. Demand & 7 & 12 & 58.3 & 24.5 & \multirow[t]{3}{*}{79.4} \\
\hline & 5. Design & 15 & 15 & 100 & 42 & \\
\hline & 6. Assortment & 8 & 10 & 80 & 33.6 & \\
\hline \multirow[t]{2}{*}{ Place } & 7.Market segmentation & 9 & 10 & 90 & 47.4 & \multirow[t]{2}{*}{85} \\
\hline & 8.Target audience & 8 & 10 & 80 & 52.6 & \\
\hline \multirow[t]{3}{*}{ Price } & 9.Competition level & 8 & 10 & 80 & 64.3 & \multirow[t]{3}{*}{33.3} \\
\hline & $\begin{array}{l}\text { 10. Effect of seasons } \\
\text { on price }\end{array}$ & 0 & 2 & 0 & 0 & \\
\hline & $\begin{array}{l}\text { 11. Loyalty program } \\
\text { (discount) }\end{array}$ & 8 & 9 & 88,9 & 35.7 & \\
\hline
\end{tabular}

A relatively simple analysis of popular websites allows identifying the feasible structure and content for the new website chapters, the typical features for design, as well as understanding how to make the website stand out among the multitude of competitors in the industry. The analysis of the advertising activities and promotion of goods and services are time-consuming tasks and imply the use of advanced methods [7]. The comparative analysis of websites identifies key performance and efficiency factors for a new business, in relation to indexes shown by competitors and leaders in the field - learning and applying others' experience is considered a progressive method for continuous improvement. Expert evaluation of website parameters reflects the effectiveness of the business organization, which proves the company's ability to attract new customers and keep them on the website. A usable tool for comparing capabilities of your own and competitors' websites are polygons of competitiveness that are graphical connections of the company's and competitors' positions by the most important dimensions, represented as vector axes. Overlaying them, one can find out strengths and weaknesses of one website in comparison to another - this marketing information is considered quite valuable and is actively researched [14].

The analysis of website traffic is done with the so-called metrics or counters that are installed into the website HTML code - in Russia, Yandex.Metrika and Google.Analytics are currently the most popular free web metrics. Generally, they monitor the number of visitors, their behavior, sources of visitors and the effective-ness of advertisement channels, etc. [9]. Particularly, one can learn about paths on the website, most active days and hours, time spend per page, and other parameters of the users' behavior. So, by constantly monitoring and analyzing the visitor numbers and conversion rates, dedicated web marketing professionals are capable of spending the advertisement budget with the maximum efficiency bringing in more target customers without over-spending on advertisement [15].

After all the necessary marketing data about a project and its target audience is collected, the actual promotion may start, employing the most appropriate of the existing methods and channels. For example, our evaluation of innovations' marketing potential performed for "Softline" company website showed that it had a very high innovations' promotion potential (at 92\%), but low potential in pricing policy and brand promotion. These results are due to the industry the company operates in - particularly, it develops and promotes websites for other businesses - but though websites are reasonably unique, they are basically innovative imitations. This company would need to prioritize components and indexes inside each component, to really manage the innovative development of the company. Having priorities would allow more optimal management and bring the both innovative and development potentials closer to the desired values. 
The study of innovations' marketing potential management shows relation between promotion potential of a new product and the company's website promotion potential. In the research, we use data from active internet users - particularly, we ran a survey implemented in Google Docs to identify the users' attitude to online ads and its effect on the website promotion potential. Into online advertisement, which is a key component of web marketing, we included the following types, per perception levels:

- social networks advertisement (SMM);

- partner website links;

- viral ads;

- context advertisement;

- SEO;

- banner advertisement.

After processing the survey materials and the experts' opinions, we were able to specify the aggregated experts' decision, which implies: a) the measure of the objects' fulfillment of the reference state, b) relative weights of the indexes in the measure. All the values were obtained according to the method for innovations' potential marketing management [16, p. 94]. The values for the promotion potential estimations were obtained for each of the components based on the total number of participants and the number of positive responses and then sorted per final importance (see Table IV).

We evaluated the relative measure of the j-th index to reach the goal value $\tilde{\mathrm{x}} \mathrm{j}$, which was specified as equal to 1 (alternatively, we could specify that if $0<x_{j}<20 \%$, then $\tilde{x}_{j=}$ $25 \%$, if $20<x_{j}<35 \%$, than $\tilde{x}_{j}=50 \%$, else $\tilde{x}_{j}=100 \%$ ).

$$
\beta_{j}=\frac{x_{j}^{0}}{\tilde{x}_{j}}
$$

Then the weight (importance) of the j-th index will be:

$$
\alpha_{j}=\frac{\beta_{j}}{\sum_{j=1}^{n} \beta_{j}}
$$

where $\mathrm{n}$ is the number of components in the promotion potential.

So, we shall obtain the values: $26 / 50=52 \%, 53 / 100=53 \%$, $34 / 50=68 \%, 25 / 50=50 \%, 48 / 100=48 \%$.

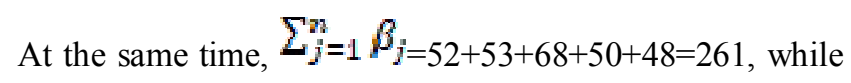
values of $\alpha_{j=52 / 261,53 / 261,68 / 261,50 / 261,48 / 261 \text {. }}$.

Then we evaluate the final estimation, equal to $C=\frac{1}{n} \sum_{j=1}^{n} \beta_{j=261 \% / 5=54.2 \% \text {. }}$
TABLE IV. THE PROMOTION POTENTIAL ESTIMATION

\begin{tabular}{|l|l|l|l|l|}
\hline Component & $\begin{array}{c}\text { Actual } \\
\text { value, } \\
\%\end{array}$ & $\begin{array}{c}\text { Relative } \\
\text { fulfillment } \\
\text { measure, } \\
\text { \% }\end{array}$ & $\begin{array}{c}\text { Index } \\
\text { weight, } \\
\%\end{array}$ & $\begin{array}{c}\text { Final } \\
\text { estimation, } \\
\%\end{array}$ \\
\hline $\begin{array}{l}\text { Context } \\
\text { advertisement }\end{array}$ & 26 & 52 & 19.9 & \\
\hline SMM & 53 & 53 & 1956 & \\
\hline SEO & 34 & 68 & 25.09 & \\
\hline $\begin{array}{l}\text { Banner } \\
\text { advertisement }\end{array}$ & 25 & 50 & 18.45 & \\
\hline Other* & 48 & 48 & 17.71 & 54.2 \\
\hline
\end{tabular}

*Includes viral ads and partner programs, see calculation in Table $\mathrm{V}$.

TABLE V. THE PROMOTION POTENTIAL ESTIMATION FOR “OTHER” TYPES OF ONLINE ADVERTISEMENT

\begin{tabular}{|l|c|c|c|c|}
\hline Component & $\begin{array}{c}\text { Actual } \\
\text { value, } \\
\%\end{array}$ & $\begin{array}{c}\text { Relative } \\
\text { fulfillment } \\
\text { measure, } \\
\%\end{array}$ & $\begin{array}{c}\text { Index } \\
\text { weight, } \\
\%\end{array}$ & $\begin{array}{c}\text { Final } \\
\text { estimation, } \\
\%\end{array}$ \\
\hline Viral ads & $12+(2+26)$ & 40 & 41.67 & \\
\hline $\begin{array}{l}\text { Partner } \\
\text { (exchange) }\end{array}$ & 28 & 56 & 58.33 & 48.0 \\
\hline
\end{tabular}

The data presented in Table 4 suggests that SEO has weight over $25 \%$, thus becoming the most important component for successful website promotion. Now, using the Bayes formula: $P(B)=\sum_{i=1}^{n} P\left(A_{1}\right) P\left(B \mid A_{1}\right)$, the authors estimate $\mathrm{P}(\mathrm{B})$, the website promotion success probability $[18,19]$. The values estimated by experts are:

$\mathrm{P}(\mathrm{A} 1)$ - probability of positive results in the focus group survey $(0.34)$,

$\mathrm{P}(\mathrm{A} 2)$ - probability of negative results in focus group survey $(0.66)$,

$\mathrm{P}(\mathrm{B} \mid \mathrm{A} 1)$ - probability of the promotion success provided the focus group survey results are positive (0.4),

$\mathrm{P}(\mathrm{B} \mid \mathrm{A} 2)$ - probability of the promotion success provided the focus group survey results are negative $(0.3)$.

So, $\mathrm{P}(\mathrm{B})=0.34 * 0.4+0.66 * 0.3=0.334$, i.e. the success probability for website promotion is $33.4 \%$. The probability estimations obtained via Bayes theorem with limited availability of information regarding new product or the actual website promotion success can be refined when more data become available.

Same actions by different consumers (who are also internet users) can have different motives, and providing for all of them to engage the users with a website is costly. The evaluation of the promotion potential allows setting priorities for the marketing tools when rationally planning budgets for website promotion campaign and overall development. Lack of fulfillment for the goals can happen due to failures in staff qualification, work deadlines and quality, or some other reasons not related to the actual marketing management of the 
innovative activities. The difference between the actual and the planned fulfillment does, as we believe, equal the risk value. The logic of the marketing risk management is traditional: identification of risks, risk evaluation (probabilities and possible losses), risk mitigation, information exchange, results monitoring and control. The marketing risk can also be defined per the 4P components: the risk of underachieving profit as the result of ineffective product, price, place, and promotion policies [8]. The failures in promotion mostly emerge because of insufficient market demand research: wrong product positioning, market competitiveness assessment, or pricing. Also, they can result from defective promotion policy, such as wrong promotion channels or inappropriate promotion budget, etc. [11].

The marketing management of innovative activities must be based on the selected new products market promotion models, allowing to increase the goal fulfillment through leveraging key success and resistance factors. E.g., the Softline company proposes to raise the conversion rate on a website by $4.86 \%$ during 1-3 working days, They also let the customer selecting the promotion tools: ads, website benchmarking, or other web marketing components. Application of such innovative approach to promotion management allows mitigating the risks for customer, as well as to increase the goals fulfillment rate.

\section{CONCLUSIONS}

As competition on today's developed markets increase, with a decline in demand and growth of supply from companies, the issues of new products' releases, development of flexible pricing policies and sustainable market promotion of the products become highly important. Effective management of innovations' promotion now is based on development and use of ICT and corporate website, considered as a part of web environment. The purpose of the website as a marketing tool is the constant search for new methods, the ways to effectively manage the promotion process. The expert evaluation of website parameters reflect the effectiveness of the company's business on the whole, its capability to attract potential customers, turn them into loyal ones, and then keep as loyal clients.

Our article summarizes the stages of the innovations' promotion goals fulfillment estimation effectiveness and efficiency, proposing the respective approach for evaluating the goal fulfillment probability and the promotion risks, the latter calculated as the difference between referential and potential innovations' promotion values. We identify the promotion potential as a constituent of the overall website potential, and further specify it as the capability to fulfill the pre-set goal using all the possible combinations of marketing components. The potential is then assessed as an integral characteristic of methodical, informational, human, and material resources, together supporting the marketing management of the innovative activities. We provide an evaluation example of innovations' promotion potential for website of Sofline company that operates in IT industry.

The factors affecting the promotion potential are identified for a website, including the promotion goals. The specification of the goals for companies, particularly for innovative ones, depends on forecasting current and, especially, future customer needs. Internet technologies increasingly allow joining the efforts of an innovative idea creator and the consumer, for increasing the innovations' promotion effectiveness and subsequent imitation of a new product. The estimation of potential for each of the innovations' marketing component is taken into account when the marketing budget is allocated, for optimizing the company's resources in the effort to fulfill the goal. The companies' capabilities in performing innovative activities depend on utilization of all the available resources, but today ICT application become of prime importance, on both national and business levels.

\section{ACKNOWLEDGEMENT}

The reported study was funded by RHSF/RFBR according to the research project No. 17-32-01087 a2.

\section{REFERENCES}

[1] E.P. Golubkov : Marketing: Strategies, plans, structure.: Publishing and Trading House "Russian Edition", Moscow, 2005, 261 p. In Russian.

[2] R.A. Fatkhutdinov, L.A. Sivkov: Innovation Management: Peter, Saint Petersburg, 2000, 624 p. In Russian.

[3] K.V. Loginov: Process management as a problem of development of domestic enterprises. Problems of the modern economy, 1 (29), 2009, pp. 187-193. In Russian.

[4] A.V. Busygin: Enterprise. INFRA-M, Moscow, 1997, 608 p. In Russian.

[5] V.G. Karchik, N.A. Zhuravlev, V. Yurchenko: Business modeling work yard. Economy railways, 4, 2012, . pp. 32-36. In Russian.

[6] S.I. Ozhegov : Russian dictionary: Russian language, Moscow, 1989, 750 p. In Russian.

[7] J.J. Lamba: Strategic Marketing. The European perspective. Nauka, Saint Petersburg, 2000, 400 p. In Russian.

[8] F. Kotler: Marketing Management. Piter, Saint Petersburg, 2006, 464 p. In Russian.

[9] D.S. Saprykin, G.I. Kurcheeva, M.A. Bakaev: Impact of social media promotion in the information age. Proc. 3 International conference electronic governance and open society: challenges in Eurasia. EGOSE Saint Petersburg, 2016. New York: ACM PRESS, 2016, pp. 229-236.

[10] A. Bjarne: Business processes. Tools to improve. RIA Standards and Quality, Moscow, 2003, 273 p.

[11] R. Hizrich, M. Peters: Entrepreneurship, or How to start your own business and succeed: Vol. I. Entrepreneur and Entrepreneurship, Progress, Moscow, 1993, $160 \mathrm{p}$.

[12] F. Kotler : Principles of Marketing: Rostinter, Moscow, 1996, 704 p.

[13] N.V. Shalanov: System analysis. Cybernetics. Synergetics: mathematical methods and models. Economic aspects, NGTU, Novosibirsk, 2008, 288 p.

[14] A.A, Aletdinova, M.S. Kravchenko, M.A. Bakaev : Crowdsourcing and the effectiveness of $\mathrm{C} 2 \mathrm{G}$ interaction in Russia. Proc. 3 International conference electronic governance and open society: challenges in Eurasia. EGOSE Saint Petersburg, 2016. New York: ACM PRESS, 2016, pp. 202-211.

[15] M. Hammer, J. Champy : Reengineering the Corporation: A Manifesto revolution in business. Publishing House of St. Petersburg University. Saint Petersburg, 1997, 332 p.

[16] G.I. Kurcheeva, M.A. Bakaev, D.S. Saprykin : Designing innovative IT mobile service for interaction with catering organizations. The Social Sciences, 11 (20), 2016, pp. 5006-5010.

[17] A. Shastitko: Transaction izderzhki. Questions Economics, 7, 1997, pp. 65-76. In Russian.

[18] E.S. Wentzel .: Probability. Nauka, Fizmatgiz, Moscow, 1969, 576 p. In Russian. 
[19] R.A. Schinova: Cost-effectiveness of marketing research. Problems of the modern economy, 2011, vol..1 (37), pp. 23-27. In Russian. 